\title{
The Influence of New Communication on Performance Clerk Assistant Administration of the Economy and the Development of the Regional Secretariat of Bandung
}

\author{
Dr. Nandang Saefudin Zenju, M.Si. \\ Djuanda University, Indonesia
}

Received: August 26, 2016 Accepted: September 28, 2016 Published: September 30, 2016

doi: 10.5296/jsss.v4i1.10086ＵRL: http://dx.doi.org/10.5296/jsss.v4i1.10086

\begin{abstract}
This study entitled Influence of Organizational Communication Against Employee Performance Administrative Assistant for Economic and Development Secretariat of Bandung. The purpose of this study to analyze the influence of organizational communication to employee performance, develop theories and concepts of organizational communication along its aspects and performance of employees and implement organizational communication theory to solve the problem of employee performance and development Economic Administrative Assistant Regional Secretariat of Bandung. The method used in this research is survey explanatory. The independent variables (X) This research is organizational communication, while the dependent variable (Y) is employee performance. The object of research on Economic Affairs and Development Administrative Assistant Regional Secretariat of Bandung. The results of the research simultaneously reveals that the variables of organizational communication empirically has an impact of $58.6 \%$ on the performance of employees consisting of a dimensional quantity of work $\left(\mathrm{Y}_{1}\right)$, quality of work $\left(\mathrm{Y}_{2}\right)$, job knowledge $\left(\mathrm{Y}_{3}\right)$, creativeness $\left(\mathrm{Y}_{4}\right)$, cooperation $\left(\mathrm{Y}_{5}\right)$ dependability $\left(\mathrm{Y}_{6}\right)$, initiative $\left(\mathrm{Y}_{7}\right)$ and personal quantity $\left(\mathrm{Y}_{8}\right)$, while the rest is equal to $41.4 \%$ is influenced by other variables not examined in this study. Organizational communication through the main form of partial, communication down effect amounted to $49.2 \%$, or more influential communication sebesar $7.6 \%$, and horizontal communication impact of $1.72 \%$ on employee performance and development Economic Administrative Assistant Regional Secretariat of Bandung.
\end{abstract}

Keywords: Communication, Performance, Organizational

\section{Preliminary}

Communication is the process of creating interaction interdependence, through a network of 
labor relations, organizational communication is very important in the process of traveling the organization to achieve its objectives. The phenomenon of organizational communication in the opinion of the Muhammad Goldhaber (2011) "the process of creating and exchanging messages in a network of relationships that depend on each other to overcome the environment of uncertain or constantly changing". The process of organizational communication will foster harmonious rhythm backed with power capable of personal individual or group through the optimum skills and expertise, and the applicable rules, so that the performance of such services to the public in line with expectations.

Understanding communication as described above is used to understand the organization's communications. Then in accordance with the approach of organizational behavior, organizational communication restrictions are sending and receiving of complex information in an organization that involves communication from superiors to subordinates, subordinates to superiors, and among fellow employees and influence each other.

The importance of good organizational communication is built in order to increase positive interaction among employees in carrying out the task of service to the public, which in turn will spur improve employee performance. Communication aims to provide and receive information, to influence others, to help others (eg, public service users), solve problems, make decisions, and evaluate effective behavior. In other words, if the organization wants to go forward, then mastering all the information, and communicate information in a way and the correct channel. Good communication downward, upward communication or communicates horizontally. Communication is done in government in order to create a good service to the community.

Issues of public services could not be separated from the aspect of resource capabilities of employees. In order for the implementation of the provision of optimum service to the achievement of high performance, the employees are required to meet specific requirements. The employee must have the competence, among others, to professional, personnel, social and provide the best possible service. In fact, still finding their dissatisfaction with the service received as a result of the performance level is still low, so that the level of public satisfaction with public services given by civil servants still deemed less.

Employee performance is an embodiment and a high working moral, even identify or translate freely that the moral quality of work is high performance employees. Hariandja (2002: 195) says about the employee's performance was "a result of work being displayed in accordance with its role in the organization". Each employee is expected to improve performance. With the increasing performance of the employees, the work will be better, the damage will be reduced and so on. The performance in question is the quality of work, quantity of work, timeliness employees work on the environment itself.

A good employee performance and optimal Became the hope of each agency, as well as the administrative assistant to the economy and Development of the regional secretariat of the city of Bandung. Based on the regulations of Bandung City Area Number number 11 in 2009 about the changes to the regulation of the blood of Bandung city number 10 in 2007 about the formation and Organization of the Secretariat of the regional city of Bandung and the 
Secretariat of the Parliament of Bandung city. Duties of principal administrative assistant to the Economic Development Secretariat and the area of Bandung has basic tasks and functions Including the following: (a) drafting Government policy areas; (B) the implementation of the device coordinating region; (C) monitoring and evaluation of the implementation of the policy of the local government; (D) the administrative and governmental apparatus construction area; (E) the implementation of other tasks given by the Mayor in accordance with the tasks and functions.

Successful achievement of the objectives of the organization Whether administrative assistant economy and the Development of the Regional Secretariat of Bandung is very dependent on the performance of employees as a resource strategy within the organization. That is, the extent to which the quality and quantity of work Reviews their employees can improve performance so as to Obtain the results of the work in accordance with the expectations of the community and in accordance with the work plan set organizations of before.

Observation of early Researchers Administrative Assistant on economy and the Development of the Regional Secretariat of Bandung city, note that the employee's performance is low. This can be seen from the indicators the problem as follows:

1) Still low level of work ability of employees in Administrative Assistant economy and the Development of the regional secretariat of the city of Bandung. It looks at the development and natural resources rated less Able to run one task anyway items, namely in terms of carrying out monitoring and evaluation into the field on the SKPD, for example: there are still reports of SKPD the which has not been in accordance with the conditions in the field.

2) Timekeeping clerk Administrative Assistant economy and the Development of the Regional Secretariat of Bandung is still low. Example: on the development and the natural resources that should go in the Office before 8:00 According to the Mayor's number 250 in 2008 about the basic tasks and functions Because raly will have to follow in the morning, due to arrive late so most employees can't follow rally morning ceremony.

The development of the science of Administration (including public administration) Periodically signitifkan that shows the difference in the emphasis of the problem in accordance with the progress of society that coupled the paradigm of thinking. Alam (2005) posited a "outline of public administration (public administration) is the activity of organizing tasks the Government (government) in accordance with the rules (rules) set out for the benefit of the people of (public)." Next Alam (2005) States that "public administration is rendered as an instrument for organizing the various components that exist in an organization that is functionally well structured." Based on the description of the specialties is the first characteristic of a public administrator, who works in an organizational unit that has a special responsibility in accordance with the rules in increasing the performance of someone.

Public policy studies is the study that developed at this time, and has Become a concern as well as involving various disciplines. Problem formulation, implementation and evaluation of policies, as well as methodological analysis is an aspect of the substance of public policy. Wahab (2010) defines "policy is very simple as guidelines for action, the policy in such a 
meaning in the form of a Declaration on the basis of the guidelines of the Act, or the direction of the action, or a program or activity of a particular plan ". The political activity of dijelakan administration policy and process as visualized as a series of stages that are most dependent are arranged According to time: the preparation of agendas, policy formulation, adoption, implementation and policy assessment policy.

The organization is a container or a place where two or more people work together to achieve the objectives that have been determined. Certainly in cooperation to achieve those goals through several taham ranging from planning (planning) Organizing (organizing), the Actuating (movement), and controlling (surveillance). For an employee, including the leadership skills of speaking, listening, reading, and writing are very important. Environment and his work are associated with language and communication. A leader will influence others to the achievement of the goal of organizations is delivered through conferences, meetings and interview conversations by telephone. Thus communication has a strategic position in the science of administration and management at this time. Without the fifth element of the management communication will not be implemented optimally.

Soetopo (2010) says "communications play an important role in the organization. Without communication organisasi will stagnate, Because no dynamics are running in the organization. Organizations in the which there are people and parts as well as functions can not carry out its function properly without any communication with each other".

Listen to the opinion of the above Soetopo, Researchers argue that communication within the organization is effective in improving suggestions on the role and functions of the people that are in the organization. This has created the interdependence with each other will be information from parties who run the functions of the Organization in order to Achieve the goals of the organization. This is where the importance of an organization's communication is built in such a way so that the objectives of the organization can be Achieved. Muhammad (2011) Suggests play three forms in communication organizations exist: (1) Communication to the bottom, (2) Communication and (3) horizontal Communication. Three forms of communication in the Organization in the organization is very important to improve the performance of employees. Understanding the performance of employees Expressed by Mangkunagara (2001), that "the performance of the employees is the result of work quality and quantity is Reached by a person in the exercise of his duty officer in accordance with the responsibility the which is charged to the employee".

Performance is the ability of the employee in performing the duties of employment in the organization/agency optimally. Employee performance is the ability in which individuals or groups within the organization can carry out its work in accordance with the goals and objectives expected or planned earlier. A good performance appraisal must be conducted with the objective to avoid or minimize existing bias evaluation factors that may be used in assessing the performance of someone in the life of the Organization as expressed by Simamora (2005) consists of the characteristics of the situation of the job description and job specification of the purpose of the assessment work, and the attitude of the employees and managers against the assessment work. Increased employee performance can be measured 
according to Gomes (2003) suggested employee performance dimensions as follows: (1) the Quantity of work, (2) the Quality of the work, (3) Job konwoledge Creativiness, (4), (5) Cooperation, (6), (7) Dependability Initiative and Personal quantity (8).

The factors submitted by the Simamoran researchers conclude that this can lead to development of the employees, because it's a leader must be able to accurately assess performance. Several factors such as performance evaluation presented Simammora (2005) in a nutshell can be outlined as follows: "the leadership should assess the employees regularly and accurately, determine individual strengths and weaknesses allows the leadership to carry out the activities that will correct the deficiency in performance". Resources are owned by the organization affect the assessment process work, by influencing the frequency, thoroughness and sophistication. In General, the more time is spent by the leadership of the little time they can devote to assess performance. Performance appraisal should be associated directly with the existing activities in the different pekerjaann description. The purpose of the performance appraisal system is the principal producing accurate and valid information regarding the behavior and performance of the members of the organization. The greater potential value to organizations. Aspects of assessment and evaluation can encourage the growth of this evaluation of the employees, pay attention to the needs of the nonprofit development officers including skills, practice, or knowledge needed someone to carry out the work in good.

The use of theory and organizational communication measurement tool and the performance as it is easy to apply in any government organization. Descriptions of the various opinions from the experts that have been mentioned above by researchers can be described as follows:

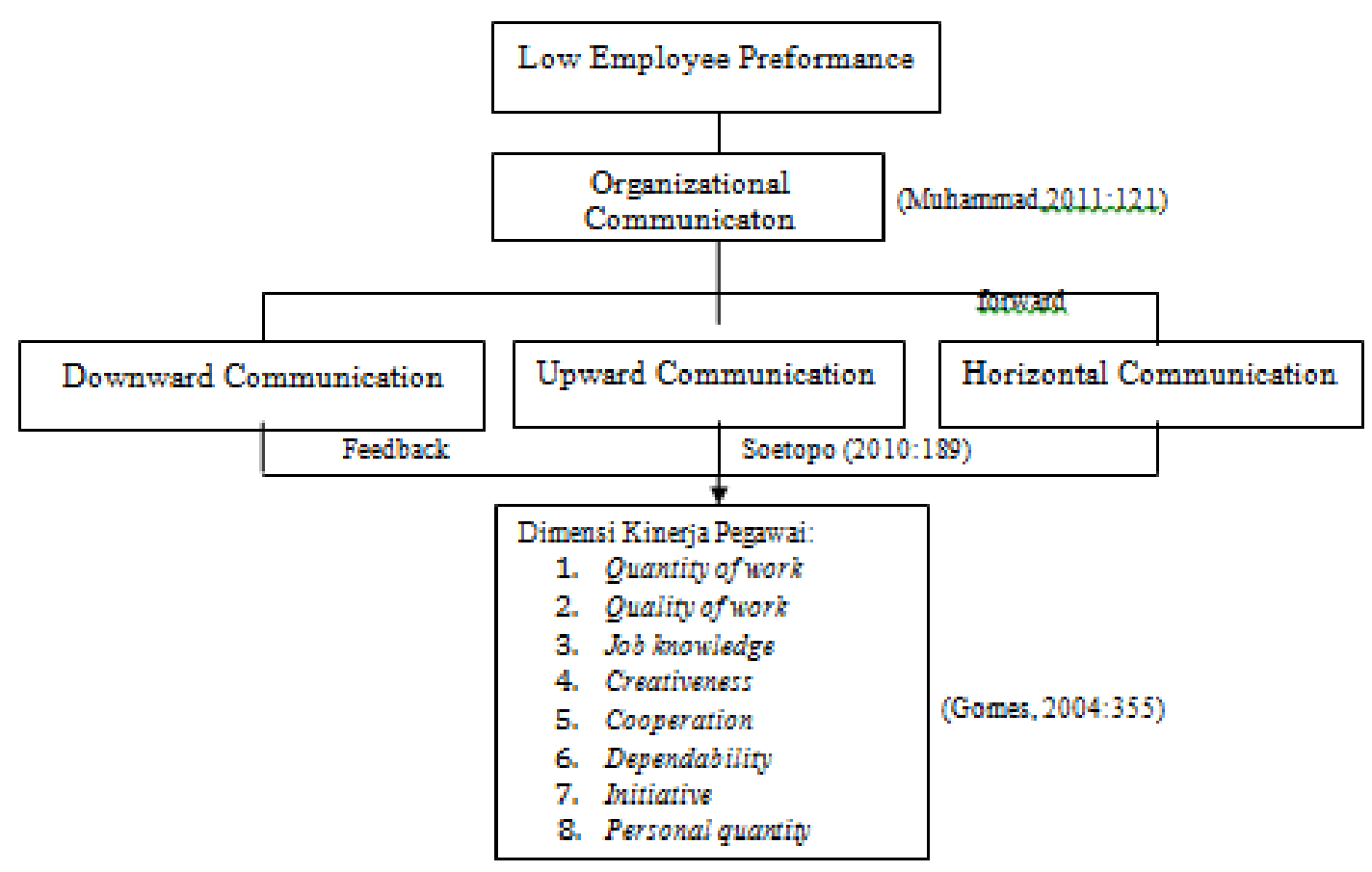

Figure 1. Mindset organizational communication and employee performance 


\section{Method}

Research methods used in this research was survey explanatory. According to Singarimbun and Effendi in Satibi (2011) i.e. this method not only explain or describe the empirical facts are found on the ground but will also describe the analysis of the influence of either simultaneous or partially between variable that becomes the focus of the research. According to Kerlinger (1973) in Sugiyono (2008) suggests that, research is research conducted a survery on large or small populations, but the data is studied data from samples taken from the population, so that relative events found, distribution, and relations between psychological or sociological variables.

Design research (research design) is a plan on how the research will be conducted and a function provides a guide to researchers about how or hypothesis that is made at the beginning of the study. (Anthony \& Sulistyastuti, 2007). The object of this design study to explain the causal relationships between variables-variables through hypothesis testing. The object of study design is viewed to be relevant to the research objectives problems answered trying to explain and describe how the influence of the variable variable bound against free, how the nature of its influence, how changes in the free variable is caused by variable is bound, or how big the influence of variable variable bound against free. As for the free variable $(\mathrm{X})$ this research is a communications organization dimensions used are: (1) Communication to the bottom, (2) communication to the atss and (3) Horizontal Communication. While the terikatnya variable (Y) is the performance of the employees of the Administrative Assistant to the economy and Development of the regional secretariat of the city of Bandung, the dimensions that are used are: (1) the Quantity of work, (2) the Quality of the work, (3) Job knowledge, Creativeness (4), (5) Cooperation, (6), (7) Dependability Initiative and Personal quantity (8).

The population of the research was the Administrative Assistant to the economy and Development of the regional secretariat of the City of Bandung, Bandung city, while members of the population made the respondent officer Administrative Assistant Economy and development Secretariat Bandung City Area by using Census techniques. For more details on the following tables are organized by:

Table 1. The target population (the respondent) clerk administrative assistant economy and the construction of the Secretariat of the city of Bandung

\begin{tabular}{lll}
\hline No & Unit & Total Employe \\
\hline 1 & Head of Section & 3 \\
2 & Head of sub-division & 9 \\
3 & Staft & 90 \\
& Total Respond & 112 \\
\hline
\end{tabular}

Source: Administrative Assistant Economy and Development Secretariat Bandung city, 2013. 


\section{IIMacrothink

Analysis of the data processing by using a line (path analysis) is to see the magnitude of the influence of organizational communication variables against variable Employee Performance administrative assistant economy and the Development of the Regional Secretariat of Bandung city design analysis conceptual lines translated into pictures as follows. Analysis of the influence of Organizational Communication independent variable (X) against the dependent variable is performance $(\mathrm{Y})$.

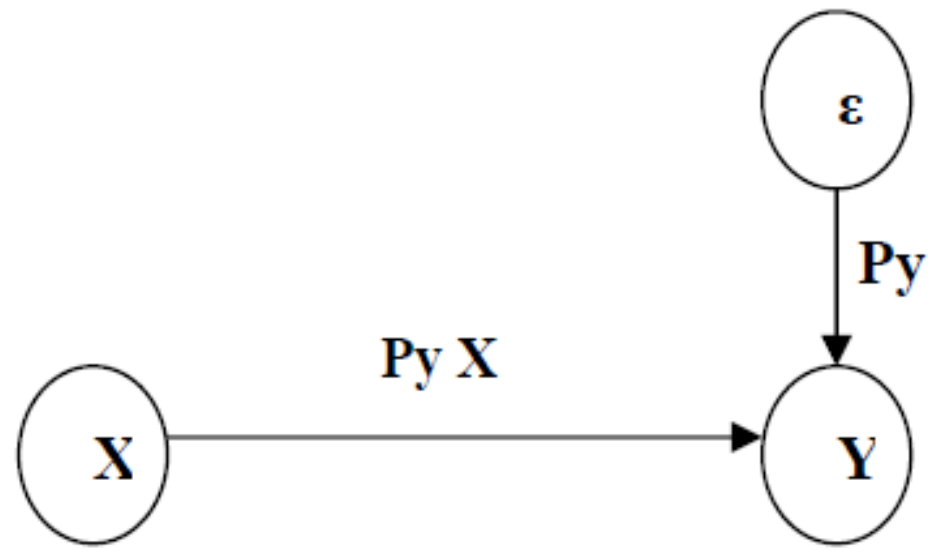

Figure 2. The structure of the influence of variable $\mathrm{X}$ against $\mathrm{Y}$ variables

Information:

$\mathrm{X}=$ Organizational communication variables

$\mathrm{Y}=$ Variable Employee Performance

Pyx $=$ The coefficient of $X$ and $Y$

$\varepsilon=$ Variables that influence outside variables studied

Py $\varepsilon=$ Variable coefficient residues / epsilon

Path analysis is conceptually translated into images as follows: 


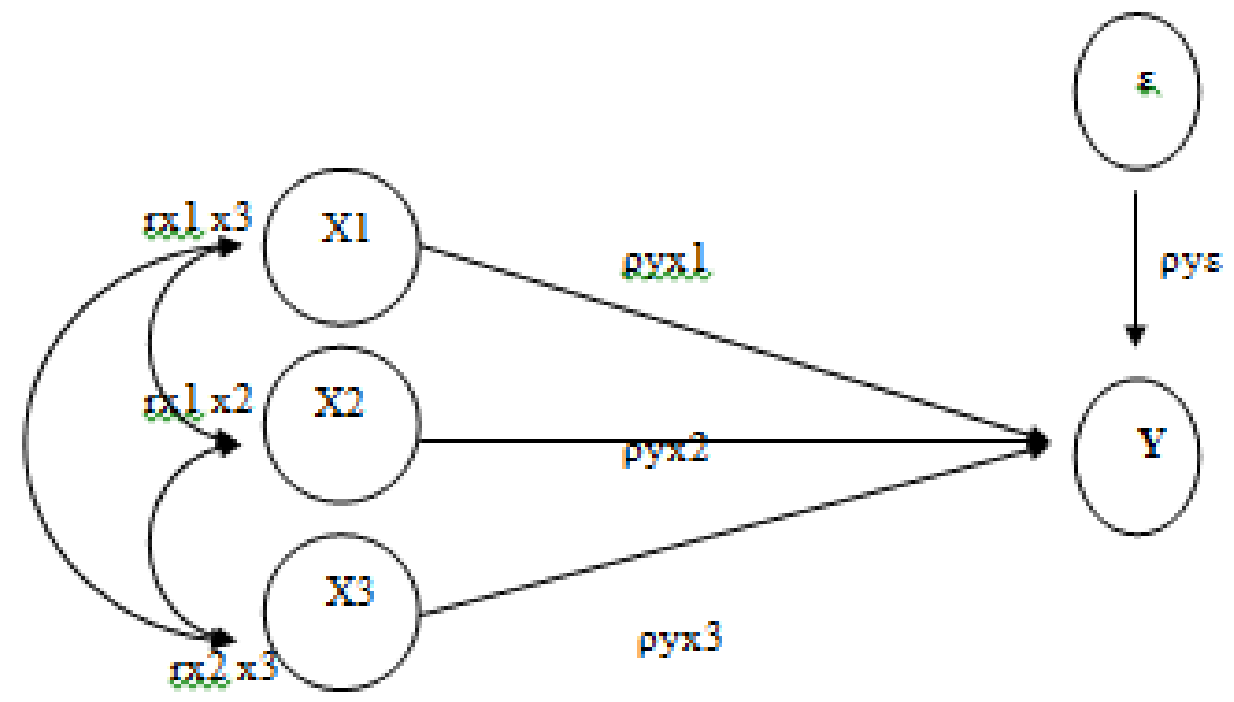

Figure 3. Structure Influence X1 ... ..X3 to Y

$\mathrm{X} 1=$ Communications Down

$\mathrm{X} 2$ = Communication to top

X 3 = Communications Horizontal

$\mathrm{Y}=$ Employee performance

pyx $1 \ldots . . \rho y x 3=$ The path coefficients of $\mathrm{X} 1 \ldots \mathrm{X} 3$ to $\mathrm{Y}$

$\rho$ y $\varepsilon=$ Variable coefficient residue, epsilon

$\varepsilon=$ The influence of other variables

$\mathrm{rx}=$ Correlation to $\mathrm{X}$

pyx 1 = That coefficient of steering / public policy, government and indoctrination, rational work to get the results of the performance of employees.

pyx $2=$ That coefficient of track work practices, suggestions and recommendations, loyalty work on employee performance.

pyx3 = That path coefficients cooperation and coordination, problem solving, support interpersonal against Employee Performance.

Furthermore, the data obtained were analyzed quantitatively by using such statistical correlation and path analysis (path analysis) with SPSS 18 to see the value of the standard Beta regression test results.

1) Validity Test 


\section{Macrothink}

A measure of validity is determined by the degree of relationship or the level of closeness (correlation) between existing items with a total score by using the formula of the Product Moment, as follows :

$$
\mathrm{r}=\frac{\Sigma \mathrm{XY}-(\Sigma \mathrm{X})(\Sigma \mathrm{Y}) / \mathrm{n}}{\sqrt{\left[\Sigma \mathrm{X}^{2}-(\Sigma \mathrm{X})^{2} / \mathrm{n}\right]\left[\Sigma \mathrm{Y}^{2}-\left(\Sigma \mathrm{Y}^{2}\right)^{2} / \mathrm{n}\right]}}
$$

Information:

$\mathrm{r}=$ Pearson correlation coefficient between the item with the corresponding variable.

$\mathrm{X}=$ Scores of items in the variable

$\mathrm{Y}=$ Score all the items in the variable

$\mathrm{n}=$ the number of respondents

2) Reliability Test

The methods used to test the reliability (reliability) of the measuring instrument in this study used consistenscy interval with engineering side two (split half) of Spearman-Brown with a mathematical model are as follows :

$$
r_{t}=\frac{2, r b}{1+r b}
$$

Information :

$R \mathrm{i}=$ Reliabillity

$r b=$ Product moment correlation coefficient

1) The Data of the two variables are measured using Likert scale measurement with isntrumen which produces ordinal scale, modified in advance using the method of successive intervals so that the retrieved data with a scale of measurement intervals.

2) Based on the interval scale maiden, calculated correlation coefficients sederhaan. The prices of the correlation coefficient between variables obtained, made in a correlation matrix inversnya matrix shaped as follows:

a) Determine the correlation matrix between variables

$\begin{array}{llll}\mathrm{X}_{1} & \mathrm{X}_{2} & \ldots & \mathrm{X}_{3}\end{array}$

Where Xixi is the Pearson correlation coefficient with the following formula: 


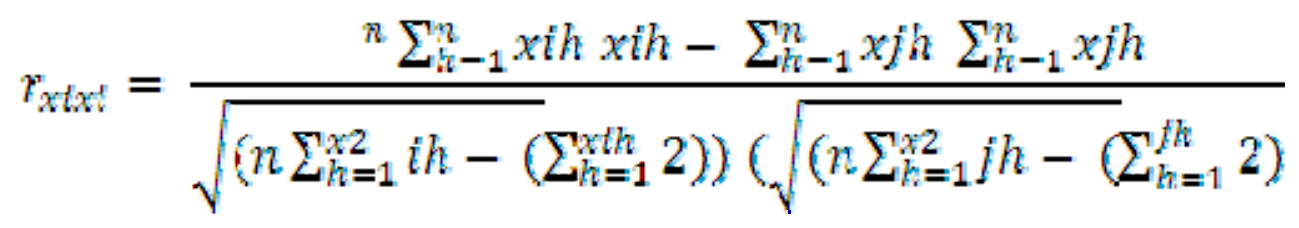

$\mathrm{i} \neq \mathrm{j}=1,2, \quad \ldots . ., \mathrm{k}$

b) Calculate the Matrix Inverse Correlation,

$\begin{array}{llll}\mathrm{X}_{1} & \mathrm{X}_{2} & \ldots . & \mathrm{Xk}\end{array}$

$\begin{array}{llll}\mathrm{CR}_{11} & \mathrm{CR}_{12} & \text {.... CRik } \quad \mathrm{X}_{1}\end{array}$

$\mathrm{CR}_{22} \quad \ldots . . \mathrm{CRik} \quad \mathrm{X}_{2}$

CRkk Xk

c) Calculate the path coefficient

$\rho Y X i=\Sigma$ CRij Ryxj ; $=1,2 \ldots$

Information:

pyxi $=$ A path coefficient of variable $x$ to variable $Y$

ryx $=$ The element or elements in row I and column J of the matrix inverse correlation or using formula :

$$
\left(\begin{array}{c}
P_{y x 1} \\
P_{r x 2} \\
\vdots \\
P_{y x k}
\end{array}\right)=\left(\begin{array}{cccc}
C R H & C R 12 & \ldots . & C R 1 k \\
C R 21 & C R 22 & \ldots & C R 2 k \\
& \vdots & & \\
C R k 1 & C R k 2 & \ldots . & C R k k
\end{array}\right)\left(\begin{array}{c}
r y x 1 \\
r y x 2 \\
r y x k
\end{array}\right)
$$

3) Determine the value of coefficient of determination (R2, other influences (P2Y $\varepsilon$ ) and the coefficient track error (py $\varepsilon$ ) using the following formulas:

$\mathrm{R} 2=\left[\begin{array}{lll}\operatorname{Pyx} 1 & \operatorname{Pyx} 2 & \ldots . \\ & & \text { Pyxk }\end{array}\right]\left[\begin{array}{c}r y x 1 \\ r y x 2 \\ \vdots \\ r y x k\end{array}\right]$

$\rho^{2} \mathrm{y} \varepsilon=1-\mathrm{R}^{2}$

py $\varepsilon=1-\mathrm{R}^{2}$

4) Perform testing of hypotheses regarding the path coefficients in two stages :

- Testing of simultaneous whole

- The research hypothesis is stated in a statistical hypothesis that:

Ho; $\rho y x 1 \ldots \rho y x 3=0$ 


\section{Ml Macrothink}

$\mathrm{H} 1$; At least there is a $\rho y x 1 \neq 0,1=1,2, \ldots 3$

Statistic test used:

$$
\begin{aligned}
& \left(\begin{array}{lll}
x \quad k & 1
\end{array}\right) \Sigma_{b i}^{k} R_{y x 1} r y x 1 \\
& F=\frac{n-k-1) \sum_{1}^{2} P_{y x 1} r y x 1}{\left(1-\sum_{1 .}^{2} P_{y x 1} r y x 1\right)} \\
& \text { Or } \\
& F=\frac{(n-k-1) R 2}{k(1-R 2)}
\end{aligned}
$$

Statistical test following the above $\mathrm{F}$ - Snedecor with degrees of freedom $\mathrm{v} 1=\mathrm{k}$ and $\mathrm{v}_{2}$ $=\mathrm{n}-\mathrm{k}-1$. test criteria, rejected if $\mathrm{F}>\mathrm{F} \alpha(\mathrm{kn}-\mathrm{k}-1)$ with $\mathrm{F} \alpha(\mathrm{kin}-\mathrm{k}-1)$ obtained from the distribution table $\mathrm{F}$ with $\alpha=5 \%$ degrees free, $\mathrm{db}_{1}=\mathrm{k}$ dan $\mathrm{db}_{2}=\mathrm{n}-\mathrm{k}-1$.

Testing of partial / individual

Steps suggested working on testing individual path coefficients are as follows :

5) Determine the statistical hypothesis to be tested.

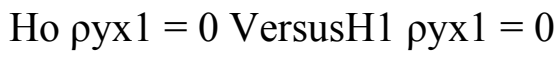

6) Determine the test statistic that will be used.

$$
t=\frac{F y x l}{\sqrt{\frac{\left(1-R^{2}\right) C R t i}{n-k-1}}}
$$

7) Criteria for the test is: if the value of $t 1>t \alpha / 2(n-k-1)$ where $t \alpha 2(n-k-1)$ is the critical value of $t$ table then Ho ersebut rejected the hypothesis test or the test is significant path coefficients are significant.

8) Conclusion

\section{Results and Discussion}

The research was done by analyzing the organizational communication variables the which is expected to have a major influence on the performance of the employees, a series of research conducted as a case study in Administrative Assistant Economy and Development Secretariat Area of Bandung research is used as the unit of analysis is the entire Administrative Assistant of employees in the economy and the Development of the Regional Secretariat of Bandung city, with the overall number of employees as many as 112 people taken as respondents. Next to the respondents filed statements in question form the which is the elaboration of indicators 
of organizational communication variables and variable performance of employees.

Indicators in each variable of research poured into statements where each statement is closed, now has five alternative answers that may be chosen by the respondent. The alternative is given a score from 5 to 1 for a positive statement and a score of 1 to 5 for a negative statement.

Based on the results of a test of the validity of the Obtained value of $R$ greater than $r$ table on any items any questions employees it indicates that all the valid statements, so that all the data can be submitted to a subsequent analysis. Validity of the test for the variable $\mathrm{Y}$ (employee performance) the which consists of 21 items all valid statement. An item is said to be valid if the value of $r$ or the value of the correlation between items with the total score indicates a significant coefficient, is said to be significant if the rtabel value of the items is less than the value of $r_{\text {count }}$. The value $r_{\text {tabel }}$ Refers to table $r$ for product moment correlation and determined the magnitude of the $\alpha=0.05$ and $n=112$. Based on the calculation value Obtained $r_{\text {tabel }}=0.334$, If there is a statement of an item is not valid then the Data Obtained could not be used for further analysis.

Table 2. Reliability test results research instruments

\begin{tabular}{lllll}
\hline No & Research variable & Reliabilility & $*$ ) Reference & Conclusion \\
\hline 1 & Organizational communication $(\mathrm{X})$ & 0.756 & $+0.70-+0.79$ & Cukup reliabel \\
2 & Employee performance $(\mathrm{Y})$ & 0.742 & $+0.70-+0.79$ & Cukup reliabel \\
\hline
\end{tabular}

Source: Data Processing 201.

The above table shows that all the variables have a value of reliability that has been reliable. The decision reliability test results show that all the instruments used to measure all items of variable organizational communication and employee performance, as has been operationalized in the operationalization of variables is acceptable or consistent reliability.

Table 3. Multiple correlation coefficient Model Summary ${ }^{\mathrm{b}}$

Model R R Square Adjusted R Square Std. Error of the Estimate Durbin-Watson

$\begin{array}{lllll} & .765^{\mathrm{a}} .586 & .574 & 6.58266 & 2.079\end{array}$

a. Predictors: (Constant), horizontal communication, downward communication, upward communication.

b. Dependent Variable: performance of employees. 


\section{Macrothink

The table above shows the coefficient of determination (R2) of 0586 means that $58.6 \%$ of variability of employee performance can be explained by the independent variable in this case the communication of the organization, which also means that there are significant organizational communications on employee performance for coefficient of determination $(\mathrm{R} 2=58.6 \%)$, or $58.6 \%$, this means that the influence of variables outside the model that is equal $y=1-\mathrm{R}^{2}=0.414$ (error). The magnitude of the path coefficients for each variable is as follows :

Table 4. Values of standardized coefficients for coefficient line

\begin{tabular}{|c|c|c|c|c|c|c|c|c|c|}
\hline \multirow{2}{*}{\multicolumn{2}{|c|}{ Model }} & \multicolumn{2}{|c|}{$\begin{array}{l}\text { Unstandardized } \\
\text { Coefficients }\end{array}$} & \multirow{2}{*}{$\begin{array}{l}\text { Standardized } \\
\text { Coefficients } \\
\text { Beta }\end{array}$} & \multirow[t]{2}{*}{$\mathrm{t}$} & \multirow[t]{2}{*}{ Sig. } & \multicolumn{3}{|c|}{ Correlations } \\
\hline & & B & $\begin{array}{l}\text { Std. } \\
\text { Error }\end{array}$ & & & & $\begin{array}{l}\text { Zero-o } \\
\text { rder }\end{array}$ & Partial & Part \\
\hline \multirow{4}{*}{1} & (Constant) & 28.658 & 3.558 & & 8.055 & .000 & & & \\
\hline & $\begin{array}{l}\text { Downward } \\
\text { communication }\end{array}$ & 3.367 & .419 & .653 & 8.027 & .000 & .754 & .611 & .497 \\
\hline & $\begin{array}{l}\text { Upward } \\
\text { communication }\end{array}$ & .699 & .418 & .141 & 1.674 & .097 & .540 & .159 & .104 \\
\hline & $\begin{array}{l}\text { Horizontal } \\
\text { communication }\end{array}$ & .193 & .482 & .034 & .401 & 690 & .507 & .039 & .025 \\
\hline
\end{tabular}

a. Dependent Variable: performance of employees.

The table explains the value standaridized cofficients or path coefficients of the variables of organizational communication to variable performance, ie the path coefficient from $\mathrm{X}$ to $\mathrm{Y}=$ 0586. The results of data processing can be made in the form of path diagram and structural similarities to include the estimated coefficient on the data processing, the structural equation is:

$\mathrm{Y}=\beta 11 \mathrm{X}+\varepsilon$

$\mathrm{Y}=0.586 \mathrm{X}+\varepsilon$

Referring to the multiple correlation coefficient table for the structure were tested showed multiple coefficient of determination and all exogenous variables tested were of $\mathrm{R} 2=58.6 \%$. This multiple determination value is the square of the multiple correlation coefficient $\mathrm{R}=$ 0765. The R2 shows that the degree of influence of organizational communication very closely when compared with other variables not studied. The calculation results can be seen in the picture below: 


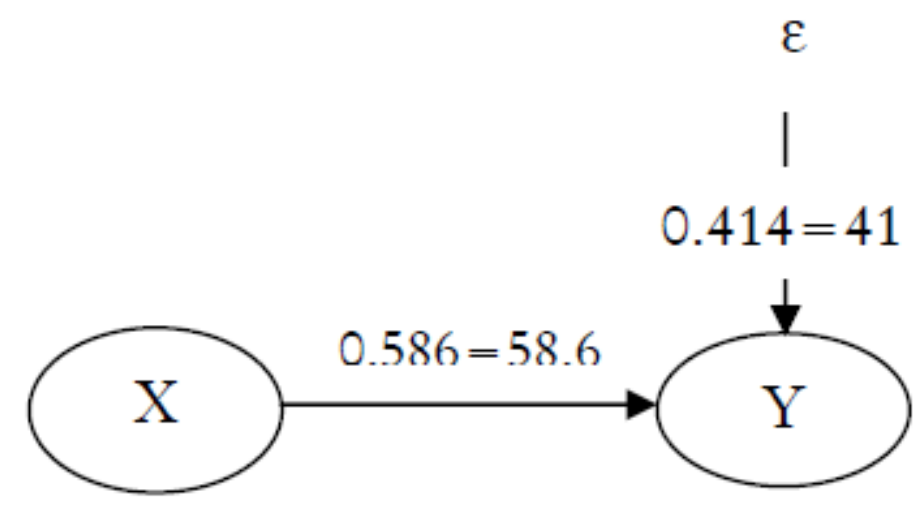

Figure 4. The magnitude of the effect of variable $\mathrm{X}$ to $\mathrm{Y}$

Based on the analysis of test contributions influence, suggesting that organizational communication variables affect the performance of employees is equal to 0586 , or $58.6 \%$. Communication organization consisting of a main form of communication downward, upward communication and horizontal communication affect the performance of $58.6 \%$, while the rest is equal to $41.4 \%$ is influenced by other variables not examined in this study.

In sub-structure is tested how much influence downward communication (X1), upward communication (X2) and horizontal communication (X3) on employee performance (Y) in the Administrative Assistant for Economic and Regional Development Secretariat of Bandung. The analytical method used is Path Analysis. The Path Analysis results are described in the following table :

Table 5. Multiple Correlation Coefficient Model Summary ${ }^{\mathrm{b}}$

Model R R Square Adjusted R Square Std. Error of the Estimate Durbin-Watson

$\begin{array}{lllll}1 & .765^{\mathrm{a}} .586 & .574 & 6.58266 & 2.079\end{array}$

a. Predictors: (Constant), horizontal communication, downward communication, upward communication

b. Dependent Variable: performance of employees.

The table above explains that the coefficient of determination (R2) of 0586, this means that $58.6 \%$ of variability variable employee performance can be explained by the independent variable in this case the main form of communication down (X1), upward communication (X2) and horizontal communication ( X3), which also means that there are significant co-operation between the main form of communication down (X1), upward communication (X2) and horizontal communication (X3) to employee performance for coefficient of 
determination $(\mathrm{R} 2=58.6 \%$ ) or also means that the influence of variables outside the model that is equal to $1-\mathrm{R} 2=0414$ (error). The value of the coefficient paths of each of the dependent variables are as follows:

Table 6. Values of Standardized Coefficients for Coefficient Line

\begin{tabular}{|c|c|c|c|c|c|c|c|c|c|}
\hline & \multirow{2}{*}{ Model } & \multicolumn{2}{|c|}{$\begin{array}{l}\text { Unstandardized } \\
\text { Coefficients }\end{array}$} & \multirow{2}{*}{$\begin{array}{c}\text { Standardized } \\
\text { Coefficients } \\
\text { Beta }\end{array}$} & \multirow{2}{*}{$\mathrm{t}$} & \multirow{2}{*}{ Sig. } & \multicolumn{3}{|c|}{ Correlations } \\
\hline & & B & $\begin{array}{l}\text { Std. } \\
\text { Error }\end{array}$ & & & & $\begin{array}{c}\text { Zero-o } \\
\text { rder }\end{array}$ & Partial & Part \\
\hline \multirow{4}{*}{1} & (Constant) & 28.658 & 3.558 & & 8.055 & .000 & & & \\
\hline & $\begin{array}{c}\text { komunikasi ke } \\
\text { bawah }\end{array}$ & 3.367 & .419 & .653 & 8.027 & .000 & .754 & .611 & .497 \\
\hline & komunikasi ke atas & .699 & .418 & .141 & 1.674 & .097 & .540 & .159 & .104 \\
\hline & $\begin{array}{c}\text { komunikasi } \\
\text { horizontal }\end{array}$ & .193 & .482 & .034 & .401 & .690 & .507 & .039 & .025 \\
\hline
\end{tabular}

a. Dependent Variable: kinerja pegawai.

Value standaridized cofficients or path coefficient of each factor with the following explanation: (1) the first coefficient $=0653$, the meaning is that communication down (X1) effect on employee performance; (2) The second coefficient $=0141$, the meaning is that the upward communication (X2) effect on employee performance; (3) The third coefficient = 0.034, the meaning is that horizontal communication (X3) influence on employee performance.

The results of data processing can be made in the form of path diagram and structural similarities to include the estimated coefficient on the data processing, the structural equation is as follows:

$\mathrm{Y}=\beta_{1} \mathrm{X}_{1}+\beta_{2} \mathrm{X}_{2}+\beta_{3} \mathrm{X}_{3}+\varepsilon$

$\mathrm{Y}=0.653 \mathrm{X}_{1}+0.141 \mathrm{X}_{2}+0.034 \mathrm{X}_{3}+\varepsilon$

Referring to the multiple correlation coefficient table for the structure being tested, the coefficient of determination and across multiple exogenous variables tested were of R2 = $58.6 \%$, the value of this multiple determination is the square of the coefficient of korealsi multiple $\mathrm{R}=0765$. The $\mathrm{R} 2$ value indicates that the degree of influence downward communication (X1), upward communication (X2) and horizontal communication (X3) closely when compared with other variables not examined.

Based on the values of path coefficients can be calculated that the influence of $\mathrm{X} 1$ to $\mathrm{Y}$ is equal to 0653 , the influence of $\mathrm{X} 2$ to $\mathrm{Y}$ is at 0141 , the effect of $\mathrm{X} 3$ to $\mathrm{Y}$ is at 0034 , with the influence of other variables is equal to 0414 for more details, the influence can be seen in the following picture : 


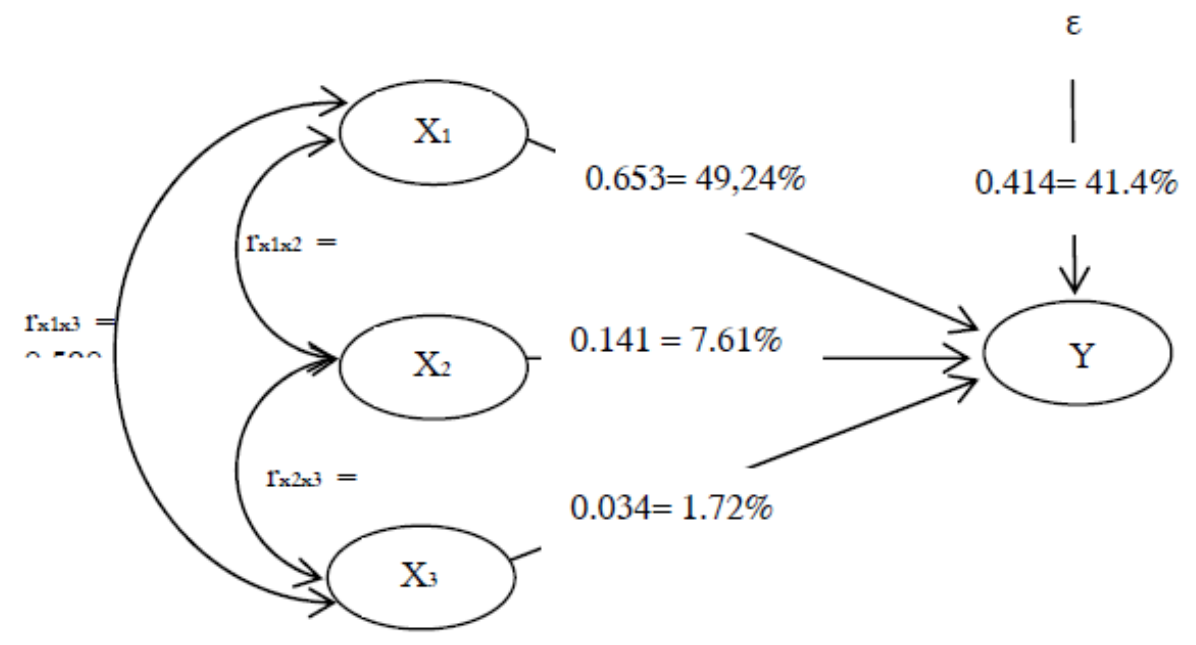

Figure 5. The amount Influence main forms of $\mathrm{X} 1, \mathrm{X} 2$ and $\mathrm{X} 3$ to $\mathrm{Y}$

Calculation that generates the magnitude values of influence, including influence of X1 to $\mathrm{Y}$ sebasar $42.6 \%$, the effect on Y X1 through X2 by $5.3 \%$ and Influence X1 to Y via X3 at 1.3\%. Total direct and indirect influence of the main forms of X1 to $\mathrm{Y}$ is $49.2 \%$. Effect of $\mathrm{X} 2$ to $\mathrm{Y}$ by $2 \%$, the effect of $\mathrm{X} 2$ to $\mathrm{Y} 5.3 \%$ memalui $\mathrm{X} 1$ and $\mathrm{X} 2$ influence on $\mathrm{Y}$ via X3 by $3 \%$. Total direct and indirect influence of the main forms of $\mathrm{X} 2$ to $\mathrm{Y}$ is $7.6 \%$. Influence $\mathrm{X} 3$ to $\mathrm{Y}$ by $0.1 \%$, the effect of $\mathrm{X} 3$ to $\mathrm{Y}$ via $\mathrm{X} 1$ by $1.3 \%$ and rafter $\mathrm{X} 3$ to $\mathrm{Y}$ through $\mathrm{X} 2$ by $0.3 \%$. Number angsung and indirect influences main form $\mathrm{X} 3$ to $\mathrm{Y}$ is $1.7 \%$. Influence together $\mathrm{X} 1, \mathrm{X} 2$ and $\mathrm{X} 3$ to $\mathrm{Y}$ is $58.6 \%$. The calculation result is clearly can be seen in the following table:

Table 7. Recapitulation Effect of X1, X2 and X3 to Y

\begin{tabular}{llll}
\hline No & Path & The direct effect and indirect $(\%)$ & Cumulative \\
\hline 1 & $\rho_{\mathrm{YX} 1}$ & 49.2 & 49.2 \\
2 & $\rho_{\mathrm{YX} 2}$ & 7.6 & 56.8 \\
3 & $\rho_{\mathrm{YX} 3}$ & 1.72 & 58.6 \\
& The influence of other variables & 41.4 \\
& Total Influence & 100.00 \\
\hline
\end{tabular}

Source: Data Results were processed, 2013.

The above data shows that the upward communication has the greatest influence on employee performance, followed by a downward communication has a strong influence on employee performance variables. While the influence of the variables is the smallest on the performance of horizontal communication.

Based on the results obtained by analysis of the influence of communication variables organization consisting of downward communication, upward communication and horizontal 
communication to employee performance $(\mathrm{Y})$, the effect of $58.6 \%$. While the rest that is equal to $41.4 \%$ is influenced by other variables not examined in this study.

The results of the analysis of the influence of simultaneous contribution test communication organisation $(\mathrm{X})$ against the performance of employees $(\mathrm{Y})$, indicating that the Organization's communication variable effect on the performance of employees is amounted to $36.4 \%$. The results of the count also means that the form of influence between the variables were in accordance with the proposed hypothesis. The research hypothesis that read "the communication of large organizations affect the performance of employees in Administrative Assistant economy and the Development of the Regional Secretariat of Bandung" is determined by the main form of communication below, communication, horizontal communication and acceptable.

The results of the interviews with Secretary Administrative Assistant economy and the Development of the regional secretariat of the city of Bandung where the organizational communication in general is already running well in accordance with the organizational form of communication. Strengthening the findings above can be detected from the Organization Forms of communication have been conducted properly, Including communication down, communication, horizontal communications and has been running smoothly. In addition, employees are expected to work Also According to the basic tasks and functions so that it can provide the best service to the people who need.

Communication organization consisting of a main form of communication downward, upward communication and horizontal communication affect the performance of $58.6 \%$, while the rest is equal to $41.4 \%$ is influenced by other variables not examined in this study. This suggests that there are other variables that affect the performance of employees apart from organizational communication. The other variables not examined in this study, such as employee motivation.

\section{Conclusions and Recommendations}

\subsection{Conclusion}

1) Simultaneously revealed that the empirical basis of organizational communication variables has provided a major influence on the performance of the employees of the Bureau of public relations, Protocol and Secretariat General Area of West Java province. This meaning that the Organization's communication was seen operationally very important and very supportive towards the performance of employees in Administrative Assistant economy and the development of the regional secretariat of the city of Bandung. The results of the findings of the study also found that the variable performance of employees at Administrative Assistant economy and the development of the Regional Secretariat of Bandung was not only influenced by variables of organizational communication, but there are other variables that also affects the employee's performance against.

2) Communication organization through the main form of communication downward, upward communication, and partially horizontal communication has an impact on employee performance and development Economic Administrative Assistant Regional Secretariat of 


\section{Macrothink}

Bandung. This is reflected in the results of empirical illustrating that variable organizational communication has been implemented in accordance with the primary form of communication organization and standard operating procedures clear job of Administrative Assistant for Economic and development Secretariat of Bandung, but operationally not completely worked effectively, so implications for the performance of employees. The organization's main form of communication is the greatest influence on the communication to employee performance, followed by a downward communication has a strong influence on employee performance variables. While the influence of the variables is the smallest on the performance of horizontal communication.

\subsection{Recommendations}

1) Researchers suggest that scientists and practitioners associated with the studies for more research that is sustainable in order to contribute to the thinking, especially in the aspect of the development of science.

2) Bureaus of public relations, Protocol and Secretariat General Area of West Java province should give serious attention to service to the public through a communications organization smoothly, so that it can improve the performance of employees.

3) the main forms of horizontal communication should be improved more by way of following up on every message or proposals submitted to the officers of the leadership.

4) Implementation of organizational communication is better, done preferably with a pattern of more intensive supervision and persuasively performed by the head of the Bureau against against the implementation of the Organization's communications in accordance with the main form of communication good communication upward, downward communication communication as well as horizontally. This is done so that the objectives of the Organization are Achieved Appropriate planning work program.

5) Appropriate policies oriented at improving the performance of employees with how to make work procedures are clear, and easily understood by employees in doing good communication in the workplace. In addition it was made also clear workflows, so employees can work through guided and ultimately can improve the performance of employees.

\section{References}

Alam, K. (2005). Public Administration in the Perspective of Theory and Practice. Bandung: University of Pasundan.

Arikunto, S. (1993). Research Methods. Jakarta: Publisher Ghalia Indonesia

Dharma, A. (2001). Management Supervision. Jakarta: Raja Bupati Press

Dwidjowijoto, R. D. (2004). Public Policy Formulation, Implementation and Evaluation. Jakarta: PT. Elex Media Komputindo.

Haris, B. (2002). Theory of Organization. Bandung: Prisma.

Indiahono, D. (2009). Dynamic Policy-Based Public Policy Analysis. Yogyakarta, Publisher 
Gaya Media.

Iskandar. (2001). Methods Suvery. Jakarta Gramedia.

Islamy, M. I. (2009). Principles of State Policy. Jakarta: PT. Raja Grafindo Persada.

Itang, S. (2006). Effect on Productivity Organisation communication Pegawa work at the Department of Industry and Trade of Sumedang.

Jones, C. O. (1994). Introduction to Public Policy (Public Policy), interpreter Intanto. Jakarta: PT. Raja Grafindo Perkasa.

Keban, Y. T. (2008). The Six Dimensions of Public Administration Strategic Concepts, Theories and Issues. Yogyakarta: Gaya Media.

Madani, M. (2011). Interaction Dimensions Actors in Public Policy Formulation. Yogyakarta: Graha Science.

Mangkunagara, A. P. (2005). Human Sumer Management Company. Bandung PT. emaja Rosda Karya.

Meki, P. (2010). Influence of vertical Communications Account Performance Against representative Consultation On Oversight Section in the Tax Office Pratama Bandung Kares. Bandung: Thesis Unpas

Muhammad, A. (2011). Organizational Communication Jakarta: Earth Literacy.

Mulyana, D. (2006). Science Communication: an introduction. Bandung: Remaja Rosda Karya.

Notoatmodjo, S. (2003). Human Resources Development Jakarta: Rineka Cipta.

Nugroho. (2004). Public policy. Jakarta: Rineka Cipta.

Prawirasentono, S. (1999). Human Resource Management, Employee Performance Policy. Yogyakarta: BPPE

Purwanto, E. A., \& Sulistiyastuti. (2007). Quantitative Research Methods. Yogyakarta: GaVa Media.

Robiana. (2009). Participatory Leadership Influence on the Performance Auditor At the Supervisory Board of West Java Province.

Rusidi. (1998). Fundamentals of Research In Rangak Development of Science. Bandung: Graduate Unpad.

Sedarmayanti. (2009). Human Resources and Work Productivity, Bandung CV. Mandar Maju. Simamora, S. (1995). Bureaucracy. Jakarta: PT. Raha Grapindo Persada.

Soetopo. (2010). Organizational Behavior. Bandung: Remaja Rosda Karya.

Son, F. (2001). Critical Paradigm in the Study of Public Policy, Change and Innovation in 


\section{Macrothink}

Journal of Social Science Studies

ISSN 2329-9150

2017, Vol. 4, No. 1

Public Policy and Space Public Participation in the Process of Public Policy. Surabaya: Student Library.

Sutarto. (2006). Fundamentals Organization. Publisher Bandung Youth Rosda paper.

Sugiyono. (2008). Methods of Research Administration. Bandung: PT. Alfabeta.

Sugiyono. (2011). Statistics for Research. Bandung: PT. Alfabeta.

Sugandi. (2011). Public Administration: the concept and the development of science in Indonesia. Yogyakarta: Graha Science.

Syafiie, Kencana, Inu. Government bureaucracy. (2004). Indonesia, Bandung: Mandar Maju.

Suryadi, S. (2009). Public Administration and Local Autonomy. Bandung: Prisma Press.

Stoner. (1992). Management Alexander Sindoro Interpreting. Editing Bambang Syaka, Jakarta: Pernhalindo.

Thoha, M. (1997). Basic Concepts of Organizational Behavior And Apliksinya. Jakarta: Rajawali

Wahab, A. S. (2010). Policy analysis. Jakarta: Bumi Aksara

\section{Copyright Disclaimer}

Copyright for this article is retained by the author(s), with first publication rights granted to the journal.

This is an open-access article distributed under the terms and conditions of the Creative Commons Attribution license (http://creativecommons.org/licenses/by/3.0/). 